International Journal of Engineering \& Technology, $7(3.25)(2018) 54-64$
International Journal of Engineering \& Technology
SPC
Website: $\frac{w w w . s c i e n c e p u b c o . c o m / i n d e x . p h p / I J E T}{2}$
Research paper

\title{
Evaluation of Structure and Accessibility of Public Space Network in Kano Central Area with the Bid to Promote Urban Cohesion and Sustainability
}

\author{
Muhammad Muktar ${ }^{1}$, Abdulaziz S. Ahmed ${ }^{2}$ \\ ${ }^{1}$ Faculty of Earth and Environmental Sciences, Bayero University, Kano, Nigeria \\ ${ }^{2}$ School of Architecture and Built Environment, Faculty of Science and Engineering, University of Wolverhampton, United Kingdom \\ *Corresponding author E-mail:mmrauf01@gmail.com
}

\begin{abstract}
There have been major concerns in the planning of both public and private spaces in Kano central area. Consequently, the entire urban fabric have been restructured due to uncontrolled developmental growth, population density, high cost of land value, unavailability of business location and poor accessibility to road network. These situations have brought about a physical and social shift in the position of Kano Central Business District (CBD) area, of which not prevented will continue to cause major urban cohesion and sustainability issue. Thus, this paper took a preemptive step to evaluate the existing problems and identify the major sustainability issues and where urban cohesion failed. A qualitative method was employed that does not only consider the study of morphological factors of the public space network in Kano CBD, but also the social, environmental and economic dynamics they generate. Thus, the data were collected through fieldwork (favoring direct contact with the territory), and analyzed using four key dimensions namely 'Form and legibility', 'Access and Connections', 'Uses and Activities', then 'Sociability and Identification'. The findings revealed that the neighborhoods that make up the CBD have lot of abandoned buildings, insufficient access routes, poor drainage system, high volume of traffic that cause lot of pollution and proliferation of solid waste that makes road network impermeable, and an aesthetic eyesore. In view of these, the study recommends a set of urban intervention strategy capable of guiding the planning and redesign of public spaces in Kano CBD in order to promote urban cohesion and a sustainable environment.
\end{abstract}

Keywords: Accessibility; Central business district; Kano; Public space network; Sustainability; Structures; Urban cohesion.

\section{Introduction}

There are major concerns in the planning of both public and private spaces in Kano central area [1]. Buildings in the area have shown sign of decay, their structural image worn out while their accessibility and connectivity pattern are characterized as very poor. Poor in the sense that, there are insufficient access routes to cater for the booming population, lack of good roads, high volume of traffic, informal captivity of roads (i.e. illegal erection of temporary structures, street hawking, vendors etc.) and lack of implementation of environmental policies. These problems have direct implications on urban mobility and on the sustainability of the central business district area (CBD).

According to [2], public space should not only promote continuity and order in a given area, but also have the natural ability to create and maintain strong local centrality, environmental quality, economic competitiveness and sense of citizenship. Therefore, provision of a good public space is very important not only to the image and life of cities, but more importantly to a diverse, tolerant and inclusive society [3]. Unfortunately, the current public space network in Kano central area does not provide such desirable elements because, it is a product of uncontrolled developmental growth, due to increase in population density [4], violations of building regulations [5], economic activities [6], and change in time [7]. These situations continues to bring about a physical and social shift in the position of Kano Central Business District (CBD) area of which not prevented will continue to cause major urban cohesion and sustainability issue. Thus, this study took a preemptive step to evaluate the structure and accessibility of public space network in Kano CBD with the bid to improve urban cohesion and promote sustainability.

Several techniques have been used to analyze the structure and accessibility in cities around the world. Techniques such as GIS Spatial analysis [8], space syntax [9], theories of Urban Spatial Design [10] and many more. These methods have helped to identify solutions to the over aching problems within an entire city fabric. Therefore, this study employed an evaluative method developed by [11] to analyze a particular Neighborhood in the Kano Central Business District area (CBD) while looking at factors that have considerable impact on urban cohesion and sustainability. But first, the literature section discussed the interrelationship between urban cohesion and sustainability as a means to clarify their relevance, and the principles that a good public space should uphold in order to design a befitting public space network. Then the methodology employed was explained, the result outlined, the solution provided and finally the conclusions were reported in the final section of the report. 


\section{Literature Review}

This section discusses the Inter-connection between Urban cohesion and urban sustainability, while also looking at the fundamental principles or standards a good public space network should uphold. Furthermore, the section delved into a brief description of the study area while establishing the nature of the area, scope and boundary of the research

\subsection{Inter-Connection between Urban Cohesion and Ur- ban Sustainability}

Various terms have been used in literature to describe cohesion in cities; the most widely used are community cohesion, social cohesion and urban cohesion. Nevertheless, each of these terms have slightly distinctive meanings particularly in the 'context' they are used. In the context of this study, urban cohesion refers to the value derived from the positive network of interaction between people, the structures they reside in and the network of public spaces they use. Thus, for an urban area to be called cohesive [12] slatted that it must:

i. Ensure permeability and continuity of the network of public spaces, thereby making all the areas easily accessible.

ii. Be balanced with a variety of urban functions such as facilities, trades, services and housing that will promote equity in access to goods and services as well as generate optimal use of spaces.

iii. Accommodate and attract different user profiles (cultures, social classes, age groups etc.) through creating livable and economically viable urban conditions.

iv. Be provided with functions that are able to attract users, be it the location, the activities they offer, or the social and economic dynamics they promote.

The concept of urban cohesion is strongly related to the lasting management of time and space [13]. In other literatures, urban cohesion is also considered as parts of sustainability, because it also aims to make an environment conducive for the present generation while taking into account the needs of future generations. However, urban sustainability has a broader perspective that encompasses urban cohesion and beyond. It is as [14] puts it, urban sustainability is usually viewed from two intertwined perspectives. The first perspective give emphasis on ecological rationality by concentrating on the most effective and efficient use of natural resources and the socio-ecological management of urban resources such as land use, energy, water, materials and other related aspects of human necessities. The second perspective focuses on ecological systems, relations and technocratic management of humanenvironmental affairs, usually through design principles, architectural forms, planning and the use of new technologies. These two perspectives are sometimes accompanied by a third one, which recognizes the wider socio-ecological networks through which the urbanization process is embedded in, and the conflicts or compromises involved in achieving urban sustainability. According to [14-15] Neo-liberalized urban sustainability framework includes urban environmental policies within the logics of ecological modernization which promotes the economic benefits of reducing environmental pollution and mobilizing a more coherent resource management operations.

Urban cohesion and sustainability cannot be separated, and this study will not be the first. The relationship between them is so strong that they are not linked to only (1) environmental factors that involve management of natural resources, reduction of carbon emissions and renewable energy but also to (2) economic and (3) social factors. The economic factors are related to the city's economical and functional characteristics while the social factors, seeks to promote social inclusion and generate integrative dynamics ([16]. In addition to these three factors, [17] added physical or functional factors. According to their study, the functional factor is related to urban form such as the continuity of space, which allows easy access to public space networks in order to promote a better understanding of an area and its functions. Thereby facilitating people's circulation and allowing the establishment of necessary links that will provide a proper functioning public space network. Nowadays, a functioning public space network is highly disputed, because we see crisis of public space in developed and particularly developing countries [18]. Streets, green areas, connectivity and open spaces are often overlooked when planning cities, thus, its quantity is diminishing. Therefore, it is important to design and plan the network of public space by taking into consideration the principles that a good public space network should uphold.

\subsection{Public Space Network Standards/Principles}

In many urban design literatures, the public space is regarded as the most important element of a city's livability [19]. Public space in its entirety "is the space that is not controlled by private individuals or organizations, and hence is open to the public. This space is characterized by the possibility of allowing different groups of people, regardless of their class, ethnicity, gender and age, to intermingle" [20]. Therefore, a properly designed public space does not only contribute to the overall visual character of a city, but they also stimulate economic activities and enhance the productivity of the city.

There are a number of principles that public spaces are expected to uphold. For urban planners, the largest concern regarding public space is that it should be fully valued by the community. However, for geographers and political scientists, the focus is different. While the urban designers' viewpoint, focuses largely upon the design of networks, squares and structures [21]. Nevertheless, [22] opined that "a good public space must have an accessible and open 'network', it should be meaningful in its design and the activities it supports must provide a sense of safety, physical and environmental comfort and convenience; it must also provide a sense of control and sensory pleasure". In short, below are the values/principles a public space should uphold.

\subsubsection{Spaces for Socialisation}

Public space should support the socialization of all. Numerous researchers who contributed to the concept of city, and specifically public space established that there is no meaning to a city that does not support the social life of the people [23]. Gregory Stone described the sociological picture of a city by studying the interactions between shoppers and cashiers [23-24]. Stone identified that despite the impersonal nature of their relations, primary relationships was being formed. Following Stone, Jane Jacobs similarly studied the intricate relations of neighbours in New York City and found that the interactions and relationships between strangers in public space could be as intimate as those between partners [2526]. These assertions illustrates that good public spaces are arenas of socialization. Thus, creating a public space that is accessible and equitable to all will develop tolerance and build a social capital connection that is important for long-term sustainability of neighbourhoods.

\subsubsection{Equitability of Public Space}

Equity is a diverse topic. However, in this study it is defined in relation to equality. This can be explained in two ways. The first is the equal provision of services across all measures [14]. The second is "output equality," which requires "equality of condition after receipt of service". These two are rarely tied together. Inequitable distributions of public space in urban centres have been demonstrated by various researchers to be problematic. For instance, when public spaces are not created in poor areas, residents either lack access to open space or must travel further to use pub- 
lic areas (for example central business district area). Furthermore, if the land value within a particular area (such as the CBD) is very high, this may decrease the socioeconomic diversity of public spaces while furthering the inequality between neighbourhoods. Therefore, equitability of space should be considered when designing a good public space network.

\subsubsection{Accessibility of Public Space}

For a public space to be called equitable and fully socialized, it must be accessible to all [27]. Accessibility "refers to the ease with which a site or service may be reached or obtained; Hence it is said to measure the relative opportunity for interaction or contact within a given area such as a park or city centres" [22]. An accessible public space is open to a variety of people and allows a variety of uses [25]. According to [18], it should be 'easy get to and get through'. It should be accessible regardless of place residence, physical disability or socioeconomic status [7]. Therefore, both physical and psychological access is required in public spaces [21]. Physical accessibility is partly based on the distribution of public space networks. The term "networks" are simply the morphological channels of the people, vehicles, goods and the information between land uses and physical components of the urban fabric [13]. Thus, [9] suggested that when the physical accessibility of the networks within a public space is properly designed, the public spaces become better utilized.

In line with the discussions on the values or principles that a good public space network should uphold, this study evaluates the network of public space in Kano's CBD while taking into consideration efficient instruments that could enhance urban cohesion and promote a sustainable environment. But first, a background of the study Area will be giving.

\subsection{Study Area}

Kano state lies between latitude $10 \mathrm{o} 31^{\text {ec }} 41.14^{\text {ee }} \mathrm{N}$ to $12 \mathrm{o} 34^{\mathrm{ec}}$

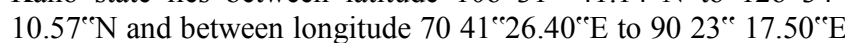
(Mustapha, 2013). As a city, it has had a rich history throughout different time-period which are categorized as pre-colonial (C.999AD to 1903), colonial (1903-1960), and post-colonial (1960 to date) era. Kano has been in existence for over 1,000 years and therefore among the oldest settlements in Nigeria. With its subjugation by the British in 1903, the colonial administration and economy gave rise to spaces such as Nassarawa, and Bompai (for the Europeans), and Sabon Gari (for non-Europeans and nonnatives) [15]. Later, Tudun Wada. Gwagwarwa and Brigade (for natives) came into existence. All together these residential units were known as Kano township - an addition to Kano City but larger. These two units formed what came to be referred to as urban Kano. (See Fig. 3.1).

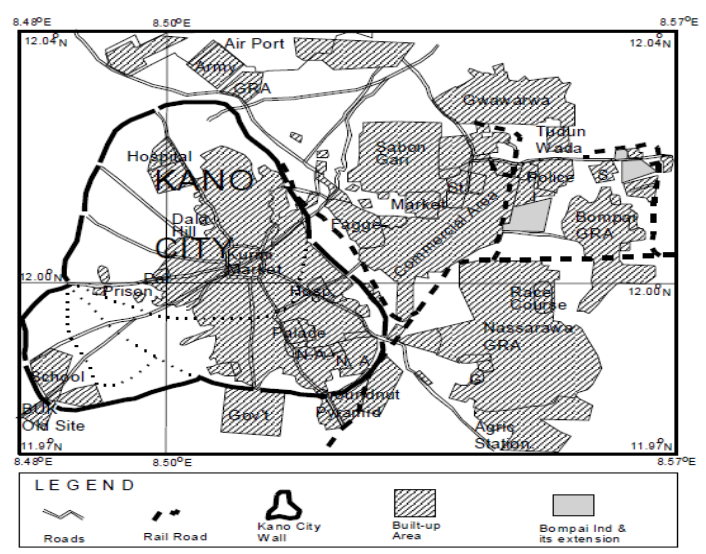

Fig. 1: Urban Kano (1967) Source: Urquhart, (1977:67); Liman, 2015)
The metropolis of Kano, which has enjoyed the position of the largest and most influential commercial area in the Sudan zone, is located between latitude $11^{\circ} 50^{\prime}$ and $12^{\circ} 07^{\prime}$, and Longitude $8^{0} 22^{\prime}$ and $8^{0} 47^{\prime}$ within the Semi-Arid Sudan Savannah Zone of West Africa (see figure 2). It covers about 499 square Kilometers (193 square miles), with a population of about 4 million as of the 2014 Nigerian census (National Population Commission, 2014). Eight local Government areas forms the Kano metropolis, these are Kano Municipal, Fagge, Dala, Gwale, Tarauni, Nassarawa, Ungogo and Kumbotso.

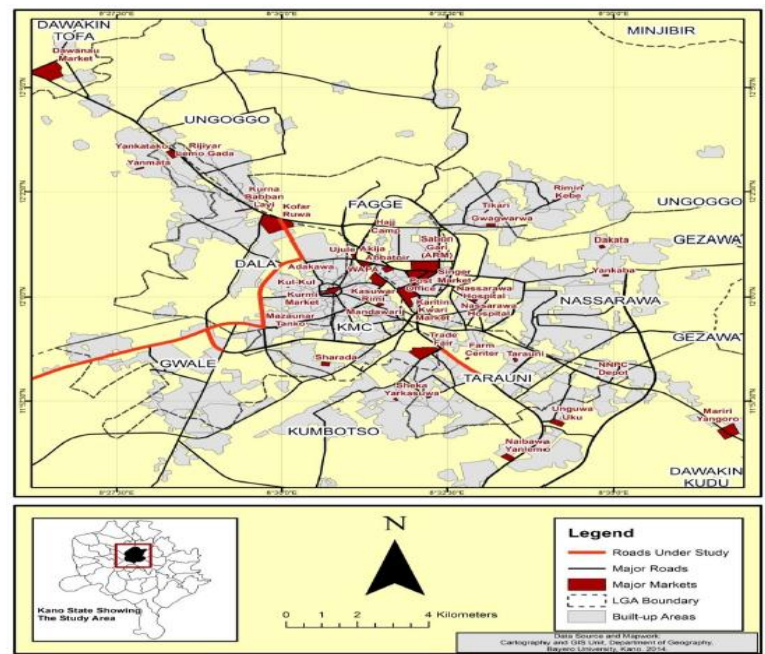

Fig. 2: Kano metropolis (source: Department of geography, Bayero university Kano (2014; Ibrahim, 2015)

Within the Kano metropolis, there exists a central business district area where all forms of socio-cultural, professional and mostly commercial services takes place. Even though there is great concern on the Kano CBD recently, it still retains some of its commercial potentialities.

\subsection{The Kano Central Business District}

Various alternative terms and definition of central business district have been offered. For instance, terms such as central area, core area, down town etc. have been used. Nevertheless, the CBD is that part of the town in which the central services of the highest order are found. It comprises of different sizes of commercial unit, public institutions, entertainment, professional, personal and office services. [22] enumerated the characteristic features of the central area to include a place with the highest level of communications, goods and services, highest land value, multi-functional land use and high population density.

The metropolitan Kano twenty years Development Plan 19631983 by travallion identified the present Gyadi-Gyadi area as the city central business district in their proposals. They recommended perimeter parking throughout the area, leaving the main area for pedestrians only. Hence, the center was designed as a series of precincts and squares to give it a sense of enclosure and scale. However, these proposals were overtaken by events and were never implemented [11]. On the other hand, Kano State Urban Planning and Protection Agency (KASEPPA) identified the CBD as the area bounded by Sarkin Yaki road in the North, Ibrahim Taiwo road in the south, Tafawa Balewa Way in the East, and finally, Katsina/Gwammaja Road in the West [11] (see figure 3).

The Parameters used in the delineation of CBD by the KASEPPA include intensity of use (specifically commercial and land value) [27] 


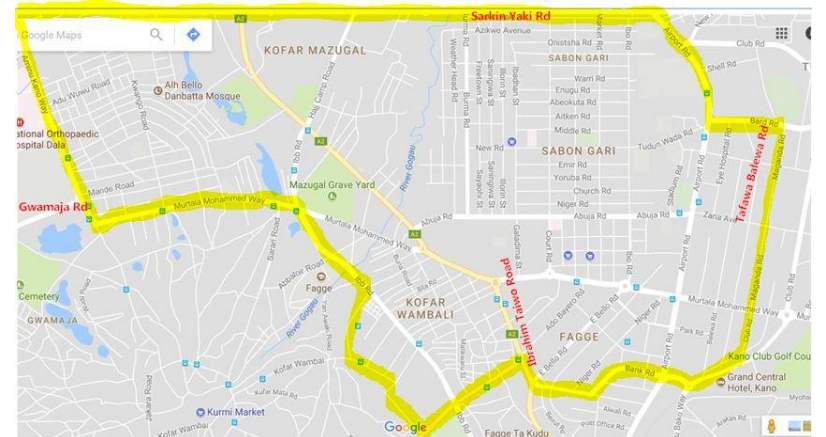

Fig. 3: Kano central business district as delineated by KASEPPA (source: Google map)

These delineative factors were not enough because they fail to consider, geographical centrality, accessibility for pedestrians and vehicles, ample parking spaces, building heights, traffic flow and potentialities for expansion. Thus, those mistakes were the genesis of the problems now encountered in the Kano CBD. For the purpose of analyzing urban cohesion and sustainability, this study focused on the area bounded by Ibrahim Taiwo road, Ado Bayero road,Kantin Kwari, Kofar wambai and Murtala Mohammad way (see figure 4). The reason for chosen these parts of the CBD was because they consist of a great wealth of commercial areas, highest land value and are the most populated part of the Kano CBD. Furthermore, there are 22 community markets, 5 regional, 7 metropolitan and 9 international markets within Kano metropolis [12] Three (3) of the international markets (i.e. Kofar wambai, Kantin Kwari and Wapa) plus a metropolitan market (Abattoir) are found within the boundaries chosen for evaluation. Thus, it is believed that these features will allow a better assessment of the public space network in this study. The next sections of this report will describe the methodology employed, the tools used, and the results obtained.

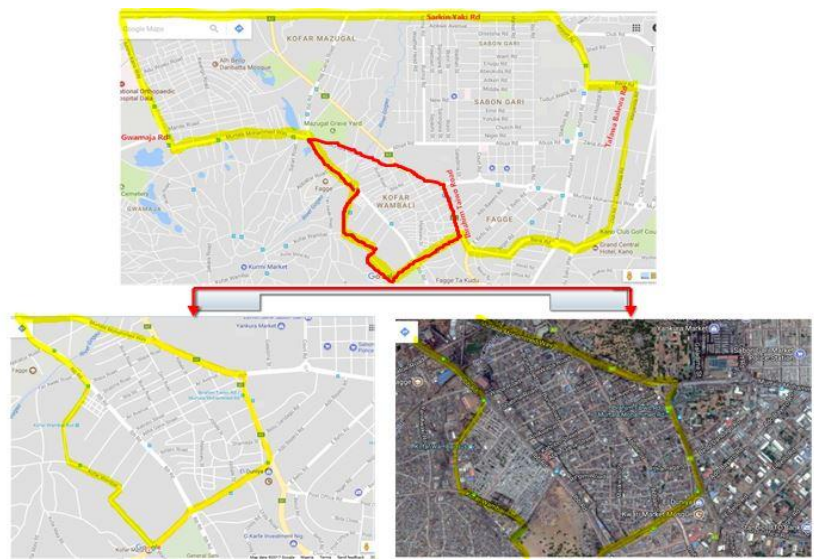

Fig. 4: Boundary of the study area KASEPPA (source: Google map)

\section{Methodology/Materials}

There are several methods identified in literatures for assessing both cohesiveness and sustainability of public space network. Nevertheless, [25] advised that the method to be employed to assess a public space should depend largely upon the characteristics of the urban network. Thus a qualitative method developed by [25] (i.e. Pinto's Evaluative Method) was employed in this study. In essence, this type of diagnose can contribute to the improvement of urban cohesion by setting priorities and introducing flexibility in the planning of a public space network. The method is divided into three distinctive steps:

i. The first step involves identification of the primary public space network of the neighborhood, which will serve as a point of focus for the entire analysis.

ii. The second step includes analysis of the network, which entails a clear and detailed diagnosis of the problems and potentialities of the public space network. It consists of four distinctive phases.

iii. The final step involves obtaining outputs of the analysis (the outputs usually dictates and defines the guidelines for the processes of urban intervention.

\subsection{First step: Identification of Public Space Network}

This stage identifies the networks of public spaces on which the entire analysis will focus. The delineation of the network is based on the areas that play a pivotal role, thus, acting as anchors, i.e., as points of attraction or generators of dynamics, that will be able to attract users to the neighborhood. According to Pinto and Remesar (2015), the important factor to lookout for when selecting an area as an anchor is that the area must be able to cause significant impact when restructuring the entire network of public space. Therefore, these areas should be selected based on the activities they offer or the social and economic dynamics they promote [25] The methodology therefore proposes four main criteria to identify the anchors, and these are:

$\begin{aligned} \text { i. } & \text { Location and Morphology } \\ \text { ii. } & \text { Differentiated supply. } \\ \text { iii. } & \text { Points of confluence. } \\ \text { iv. } & \text { Points of Attraction. }\end{aligned}$

Once the main anchor spaces are identified, the next step is to analyze the primary connections/links between them. These connections, together with the identified anchor spaces, will constitute the primary network of public spaces in the neighborhood, i.e. where the largest and most diverse number of activities and functions are concentrated, and which generate major economic, cultural and social opportunities.

Furthermore, the methodology takes into account the characteristic of multiple integration of networks. In this regard, the proposed methodology, takes into cognition the interaction between the internal networks of the neighborhood with the surrounding networks beyond the boundaries (i.e. external network). This is important not only from the perspective of the mobility of citizens, but also with regard to the diversity of activities that are capable of promoting relationships of complementarity with the various networks of the city.

In summary, the network of public spaces, on which the analysis of cohesion will focus, must consist of [1] a set of anchor spaces (local scale and the scale of the city), [2] the main links between these anchor spaces and [3] the primary connections between the internal network of public spaces in the neighborhood and external networks. Therefore, the sum of these spaces will establish the basic "grid" for the analysis of urban cohesion in the neighborhood.

\subsection{Second Step: Cohesion Analysis}

At this stage, the central body of analysis is developed by taking into account the identified public space network of the neighborhood. In line with the definitions for urban cohesion, the analysis is structured on four key dimensions also known as descriptors [26]:

i. $\quad$ Form and Legibility - An easily legible urban fabric that promotes continuity at the expense of fragmentation, that is balanced in its dimensions, allowing the existence of reference elements, contributes to the network cohesion.

ii. Access and Connections - A cohesive network is easily accessible, and allows the movement of their users comfortably with no obstruction, thus making it pleasant to use.

iii. Uses and Activities - The uses and activities are the basis of social and economic dynamics generated in a network, without which, it is not possible to build a cohe- 
sive territory. They are the generators of flows and movements of users in the public space network.

$i v$. Sociability and Identification - Sociability has to do with the relationships and interactions that users establish among themselves, in public spaces, which is an essential condition for urban cohesion.

The above descriptors are formulated in order to describe the performance of a given territory by looking at factors such as; conditions of infrastructures, layout of public space networks, connectivity, social avenues, symbolic elements, public space uses etc These formulated descriptors are qualitative in nature, because they integrate beyond the physical and morphological factors related to the existing social and economic aspects of the public space, such as; how activities are developed in the public space and how users live and accommodate the spaces. To obtain these required information; a set of question is presented against each descriptors. This is represented schematically showing the dimensions, descriptors and a set of questions we intend to answer (see figure 5).

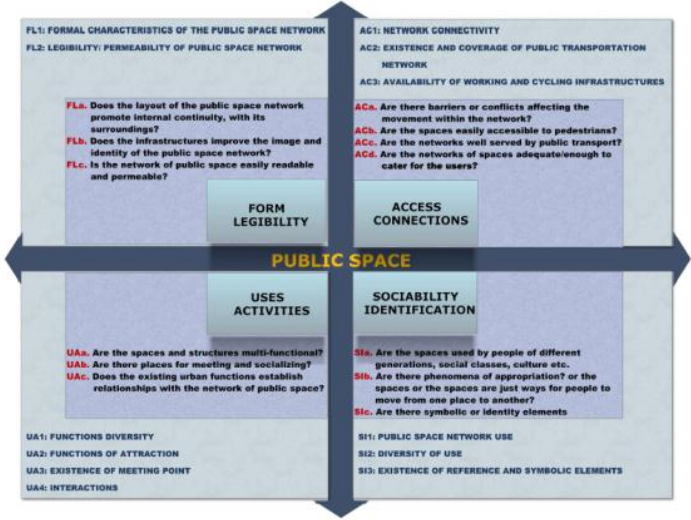

Fig. 5: Schematic representation of the analysis, dimensions and descriptors (source: adapted from Pinto and Remasar, 2012)

The information required for each of the descriptors is collected through fieldwork. It is through this process that the main problems and potentialities of the urban neighborhood will be found.

After identifying the main cohesion problems, a structural analysis matrix is used to ascertain the degree of influence that some problems exert on others. This is because understanding their relationships leads to the identification of determinant and dependent problems of urban areas. The determinant problem in this context is that problem that exerts greater influence over the remaining problems and therefore it has a greater potential to generate a significant effect of change in the weakness of the public space network.

\subsection{Final Step: Final Outputs}

This is the last step of the proposed methodology. The information in the final step is dictated by the results obtained in the previous steps. Therefore, any solution obtained is discussed in this stage.

\section{Results and Findings}

This section will follow to the letter the methodology explained in the previous section and report the findings accordingly.

\subsection{Identification of the Public Space Network}

As stated earlier, the Kano CBD was delineated by the KASUPDA to be the area bounded by Sarkin Yaki road, Ibrahim Taiwo road, Tafawa Balewa road and finally Katsina/Gwammaja road. This delineation was based on intensity of use (specifically commercial and land value). Having said that, the scope of this study was limited to some strategic neighborhood in the CBD, which is bounded, by Ibrahim Taiwo road, Ado Bayero road, Kantin Kwari, Kofar wambai and Murtala Mohammad way. These parts of the CBD were selected because of the activities they offer and the social and economic dynamics they promote. As explained in the literature section, the areas consist of a great wealth of commercial outlets that have significant history, which dates back to the colonial times. Furthermore, they are characterized as the major commercial point of attraction in Kano metropolis because of the 3 international markets they encompass such as Kofar Wambai, Kantin Kwari and Wapa [27].Therefore, these areas will act as the anchor spaces in this study.

Table 1: Important Markets selected as anchor spaces

\begin{tabular}{|l|l|l|l|c|c|}
\hline S/N & Name & Age & Importance & Status & $\begin{array}{l}\text { Nature of } \\
\text { commodity }\end{array}$ \\
\hline 1 & $\begin{array}{l}\text { Kantin } \\
\text { Kwari }\end{array}$ & 1934 & International & Exist & Single \\
\hline 2 & WAPA & 1959 & International & Exist & Single \\
\hline 3 & Abattoir & 1967 & Metropolitan & Exist & Single \\
\hline 4 & $\begin{array}{l}\text { Kofar } \\
\text { Wambai }\end{array}$ & 1977 & International & Exist & Mixed \\
\hline
\end{tabular}

The sum of the anchor spaces, the connections between them and the primary connections between the internal network of public spaces in the neighborhood and external networks constitute the basic "grid" for the analysis of urban cohesion in this study (see figure 6).

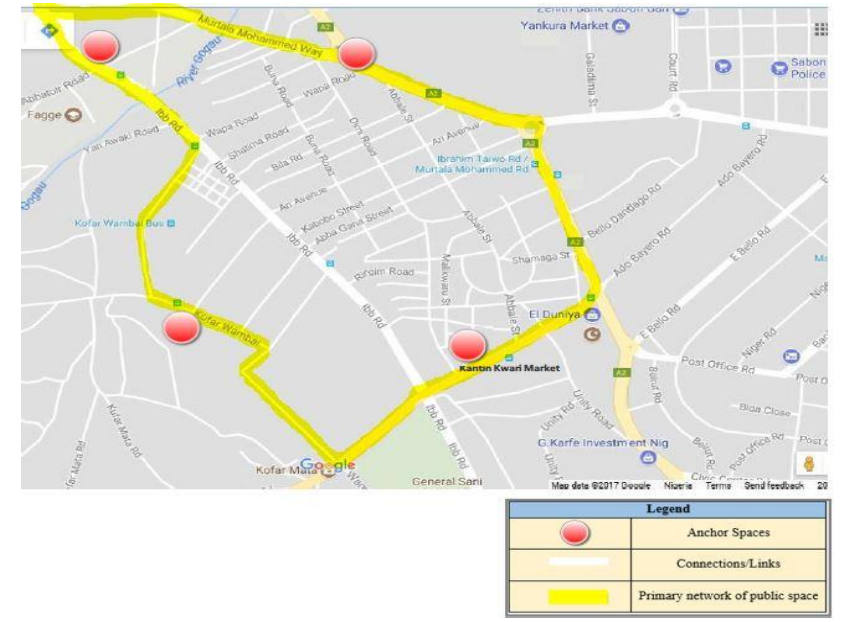

Fig. 6: Identified public space network within Kano CBD (source: Google map)

\subsection{Urban Cohesion Analysis}

As stated in the methodology section, the analysis of urban cohesion was structured on four key descriptors namely; form and legibility, access and connections, uses and activities, then sociability and identification. Thus, following a set of question presented against each descriptors in a schematic diagram (refer to figure 5 ) the following results were revealed.

\subsubsection{Form and Legibility}

The first question (i.e. FLa) addresses whether the layout of the public space network promotes internal continuity with its surroundings. Certainly, the area of Kantin Kwari, Ibrahim Taiwo road, Wapa road and Abattoir road have a fairly good layout of public space network that could promote internal continuity if not for obstructive factors that would be discussed later. However, Kofar Wambai has a very poor layout of networks with narrow streets that limits access for vehicles and pedestrians. Furthermore, there are insufficient internal-connections in Kofar Wambai area that could permit internal flow and continuity with its surroundings (this is evidently shown in figure 6 above). Therefore, in the event of fire outbreak the area will be difficult to contain. 
On the question of infrastructure (i.e. FLb), this study analyzed the conditions related to buildings, roads and storm water drainage networks. On average, the results shows that the infrastructures are in a poor state and do not improve the image of the public space network. Majority of the buildings in the scoped CBD are old with their image worn out while some are practically abandoned. The concentrations of these types of buildings are situated in Kantin Kwari area (i.e. the textile market) (figure 7).
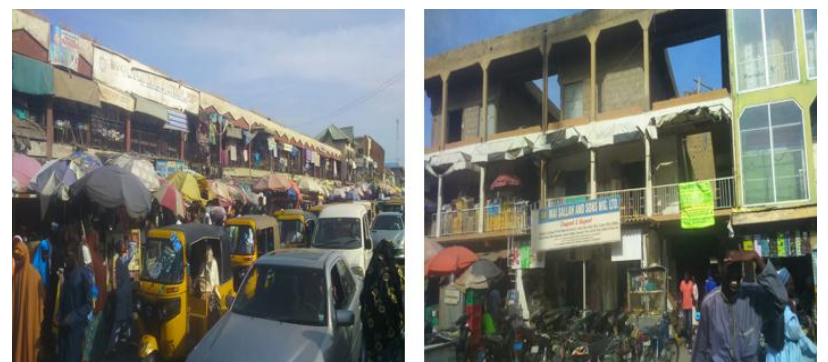

Fig. 7: Abandoned and worn-out image of Buildings in Kantin Kwari Market (source: fieldwork)

The storm water drainage facilities within the grid in this study are mostly open and clogged with loose soil, leather and solid waste matter, which are mostly rotten. This is apparent in most part of Ibrahim Taiwo road, Abattoir and IBB road (which is linked to Kofar Wambai and Kantin Kwari (figure 8).During the rainy seasons, the roads and channels become overflown with storm water and flows on the road. Furthermore, the rotten solid waste accumulated within the channels results to bad odour, and a breeding ground for all sorts of insects, which presents a health risk to the users in the neighbourhood and an aesthetic eyesore to visitors.
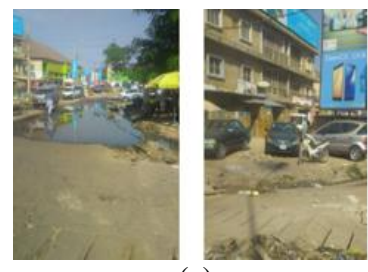

(a)
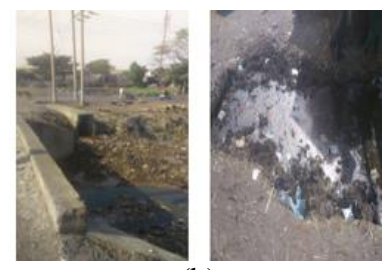

(b)
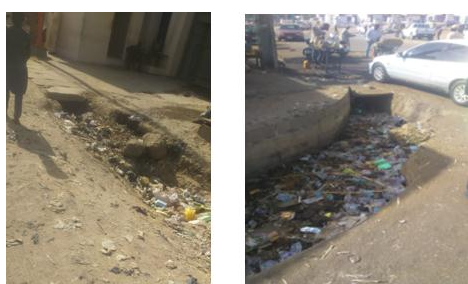

(c)

Figure 8a: poor drainage in Ibrahim Taiwo road; 8b: open and clogged drainage in Abattoir area and; 8c: blocked and poor system of drainage along IBB road (source: fieldwork).

The primary road network that makes the boundary of the study area is dual carriage. These roads are tarmacked. However, the road (i.e. Murtala Muhammad Way) between the two roundabout of Ibrahim Taiwo road and WAPA road is in a poor state with virtually no "median strip" (see figure 9a). This is partly due to the abandoned overhead bridge project, which is now causing major sustainable problems such as creating a haven for criminals and beggars, a place for undesignated parking and a dumping ground for solid waste (see figure $9 b$ and $c$ ). Furthermore, most of the secondary road network are either having potholes or are untarred (see figure 10).

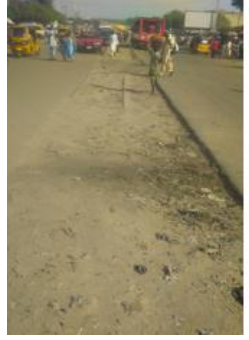

(a)

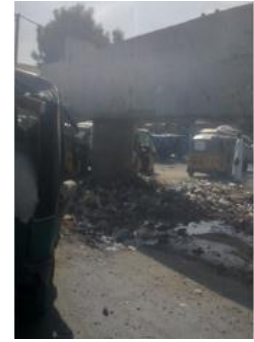

(b)

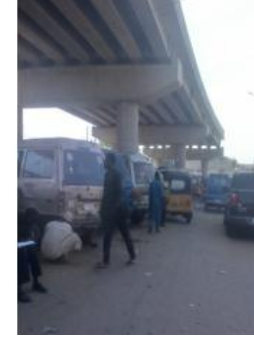

(c)
Figure 9a: poor state of Median strip; 9b: dumped solid waste under bridge; 9c: Undesignated parking (source: fieldwork)

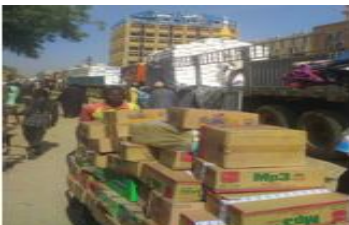

(a)

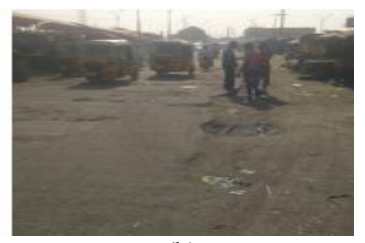

(b)
Fig. 10a: untarred road; b: Road with lots of potholes (source: fieldwork)

On the issue of readability and permeability of public space network (FLc), the study revealed that the networks are easily readable; however not all the spaces are easily permeable. This is largely due to intensity of parking in undesignated areas, illegal erection of temporary shades by roadsides, street hawking and dumping of solid waste on roads (see figure 11).

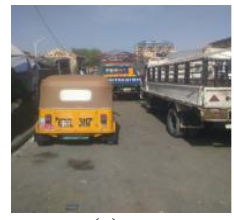

(a)

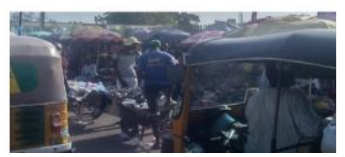

(b)

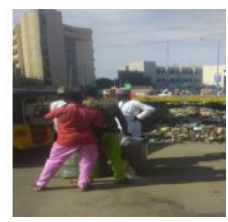

(c)
Fig. 11a: Poor parking; 11b: Illegal erection of shades on road and street hawking; 11c: Built up of solid waste on roads (source: fieldwork)

\subsubsection{Access and Connections}

Ease of access in cities is a fundamental requirement that improves interaction and sustainability of every society. According to [28], the central area of a city is characterized as a place with high population density, big capital accumulation and more accessibility/connection. Thus, it was paramount to evaluate the network of connection in this study. The first question in this section (i.e. ACa) addresses whether there are barriers or conflicts affecting the movement within the networks in the study area (refer to figure 5). Undoubtedly, there are barriers affecting the free flow of people within the networks of public spaces and these are related to poor parking, dumping of refuse on roads and high volume of traffic.

Within the study area, there are no specifically designed parking lots to cater for the booming population. Therefore, people use roadsides, under bridges and sometimes alleyways for parking purpose (see figure 12).

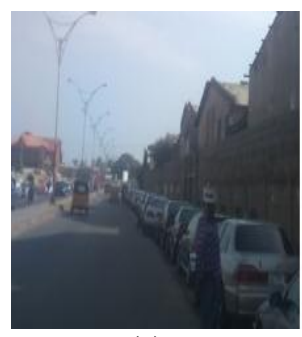

(a)

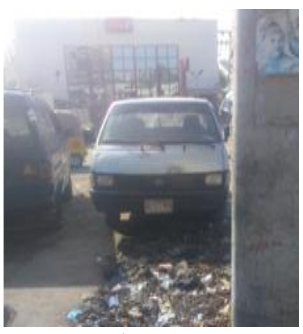

(b)
Fig. 12a: Roadsides parking on IBB road; 12b: Parking under bridge (source: fieldwork) 
This situation, coupled with illegal erection of temporary shades causes obstruction to movement by both pedestrians and vehicles. Along Kofar Wambai market and Kantin Kwari area, the Eid Ground (Religious gathering Ground) is used for parking space. Notwithstanding, this was still not adequate to cater for the population. In addition, dumping of waste on road also affects the movement in some part of the study area such as Ibrahim Taiwo road, Murtala Muhammad way and abattoir road (see figure 13). Apart from obstruction of movement, illegal dumping is the primary cause of land, air and water pollution. The health and safety risks of illegal dumping are so great that it can affect an entire community.
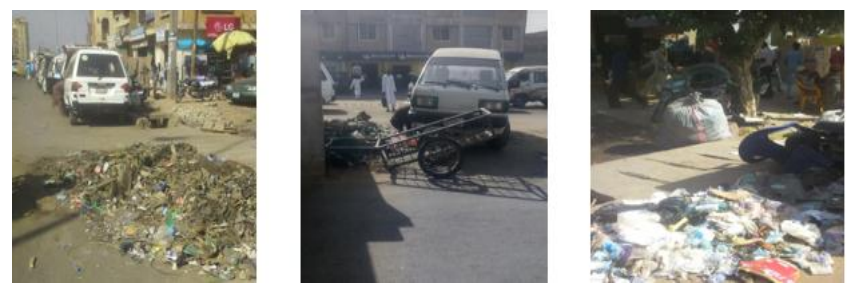

Fig. 13: Refuse causing obstruction of flow (source fieldwork)

Finally, there are evidence of high volume of traffic in the study area due to poor parking, insufficient access routes and inadequate traffic control facilities such as markers, signs and signal devices that could inform, guide and control traffic. Although, there are few traffic lights in the study area, traffic is still mostly controlled by the Kano Road Traffic Agency (KAROTA) personnel (see figure 14).

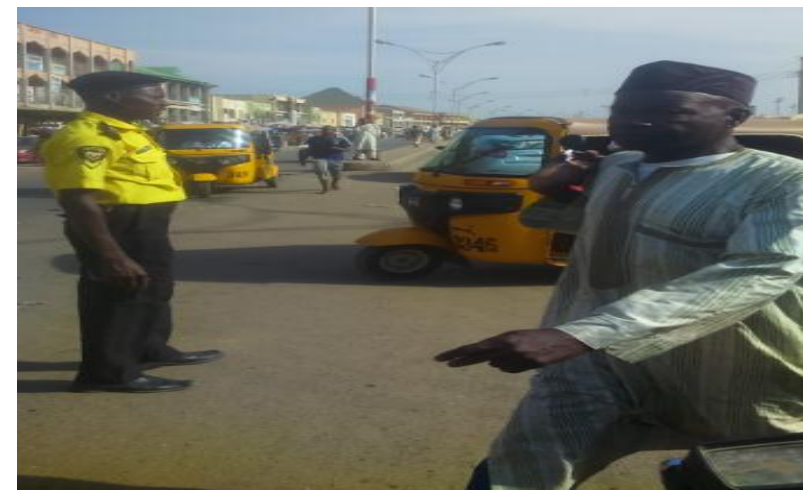

Fig.12: Traffic control personnel (KAROTA) (source: fieldwork)

On the issue of ease of access to pedestrian $(\mathrm{ACb})$, the field survey revealed that most of the network in the study area is faced with vehicular-pedestrian conflict. The spaces left for pedestrians are hijacked by vehicles and used as parking spaces, which in turn compels pedestrian to either use the median strip as access routes or even walk on the roads (see figure 15). This situation continues to threaten the life of pedestrians in the public space. Nevertheless, the spatial planning of the CBD did not cater for 'pedestrian only' access routes, thus, this conflict between vehicles and pedestrians was bound to manifest.

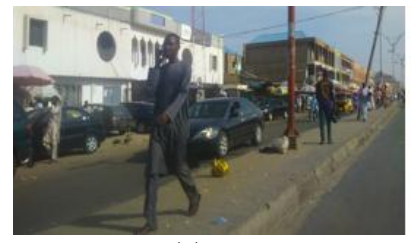

(a)

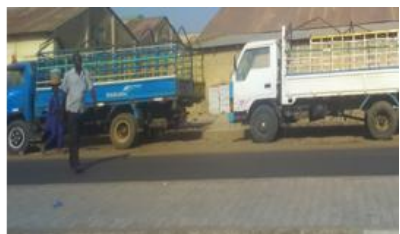

(b)
Fig.16a: pedestrians using median strip as access; b: Vehicles high jacking pedestrian route (source: fieldwork)

On the issue of public transport availability (ACc), The networks within the study area are well served by public transport in the form of busses, taxis and mostly Auto rickshaw popularly known as 'keke Napep' in Nigeria. The Keke Napep is widely used because of its availability and flexibility in Narrow spaces due to its small size. However, the drivers of these urban transport vehicles do not adhere to the specific pick-up stations in the study area, thus they stop everywhere on roads to pick passengers. The same situation applies to buses and taxis. This situation causes lots accidents, discontentment and high traffic. Finally, the results on the fieldwork in this study reveal that the networks of spaces in the scoped CBD are not sufficient for the growing population.

\subsubsection{Uses and Activities}

The first question (i.e. UAa) in this study looks into multifunctionality of spaces and structures in the study area. The study revealed that the public spaces and structures in the study grid are mostly for commercial purposes with few residential buildings. Therefore, the spaces and structures are not multi-functional. Consequently, this answer the question (i.e. UAb) that there are no places designed for meeting and socializing such as parks, squares, cinema and recreational centers etc.

The final question in this section (i.e. UAc) addresses the interrelationship between the existing urban functions in the scoped CBD with the network of public space. The high attractor potential of the scoped CBD (i.e. commercial activities) certainly causes high flow of users. However, the congestion they cause due to various factors explained earlier are restricting the comfort of users and limiting its use.

\subsubsection{Sociability and Identification}

This section addresses three questions (i.e. SIa, SIb and SIc), related to; urban diversity, phenomena of appropriation and the presence of symbolic/reference elements. The fieldwork thus shows that the CBD certainly attracts people of different generations, social classes, culture, people with disabilities etc. because of the commercial activities appropriated for the spaces. However, due to the difficulty of access in some areas, people with disabilities and the generational diversity of users is limited. The symbolic or reference elements present in the study area are some of the ancient Gates of Kano (i.e. Kofar Abbale and Kofar Wambai see figure 17) which were constructed as a major part of protective walls built around the ancient city of Kano to serve as major point of entry and exist and ensuring that invaders had constricted access. It is now declared as National Monument.

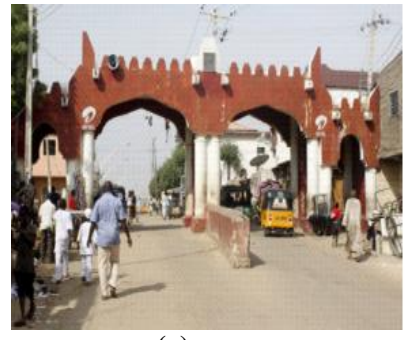

(a)

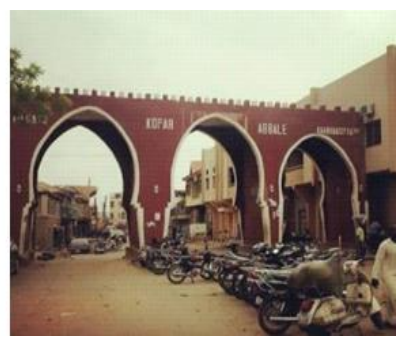

(b)
Fig. 17a: Kofar Wambai; (b) Kofar Abbale (source fieldwork)

\subsection{Final Output}

As stated in the methodology section, the final step will see the application of a structural analysis matrix developed by [29]) which helps to identify the problems with the highest degree of influence (i.e., determinant problems) over the others (i.e. dependent problems). However, it is important to recognize other problems in the graph such as connection problems and autonomous problems (i.e. those that are independent or not controlled by others). Below are the representations of the identified problems under each category in the structural analysis graph. 


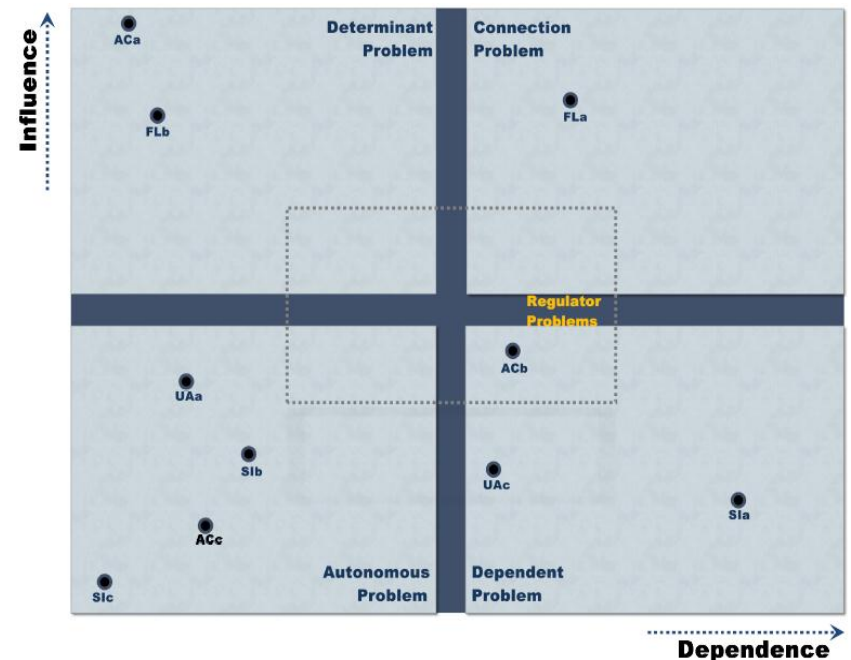

Fig. 18: Structural analysis graph (adapted from Pinto and Remasar, 2012)

From the graph above, the identified CBD problems are tabulated in table 2:

Table 2

\begin{tabular}{|c|c|c|}
\hline CBD problems & & Description \\
\hline \multirow[t]{2}{*}{$\begin{array}{l}\text { Determinant prob- } \\
\text { lems }\end{array}$} & $i$. & $\begin{array}{l}\text { ACa: This is related to the barriers af- } \\
\text { fecting the movement within the net- } \\
\text { work of public spaces such as poor } \\
\text { parking, dumping of refuse on roads } \\
\text { and high volume of traffic. }\end{array}$ \\
\hline & ii. & $\begin{array}{l}\text { FLb: This is related to the problem of } \\
\text { infrastructure that affects the image of } \\
\text { the public space network such as nature } \\
\text { of buildings, storm water drainage sys- } \\
\text { tems, and roads. }\end{array}$ \\
\hline \multirow[t]{3}{*}{ Dependent problems } & $i$. & $\begin{array}{l}\text { ACb: This is related to the problems of } \\
\text { ease of access to pedestrian, particular- } \\
\text { ly vehicular pedestrian conflict. It } \\
\text { shares some relationship with other } \\
\text { problems (i.e. determinant, dependent } \\
\text { and connection). }\end{array}$ \\
\hline & $i i$. & $\begin{array}{l}\text { UAc: This addresses the problems of } \\
\text { interrelationship between the urban } \\
\text { functions and the network of public } \\
\text { spaces such as comfort and maximum } \\
\text { usage of spaces. }\end{array}$ \\
\hline & iii. & $\begin{array}{l}\text { SIa: This is related to the problems as- } \\
\text { sociated with the uses of public spaces } \\
\text { by people of different generations, so- } \\
\text { cial classes, cultures, disabilities etc. } \\
\text { such as congestion, limits of access etc. }\end{array}$ \\
\hline \multirow[t]{4}{*}{$\begin{array}{l}\text { Autonomous prob- } \\
\text { lems }\end{array}$} & $i$. & $\begin{array}{l}\text { UAb: This is related to the availability } \\
\text { of spaces for meeting and socializing. }\end{array}$ \\
\hline & ii. & $\begin{array}{l}\text { SIb: This is associated with the activi- } \\
\text { ties appropriated for the spaces }\end{array}$ \\
\hline & iii. & $\begin{array}{l}\text { ACc: This is related to the problems of } \\
\text { public transport in the public space } \\
\text { network }\end{array}$ \\
\hline & $i v$. & $\begin{array}{l}\text { SIc: This is related to presence of sym- } \\
\text { bolic or reference elements }\end{array}$ \\
\hline Connection problem & $i$. & $\begin{array}{l}\text { Fla: This is related to the layout of } \\
\text { network including internal flow and } \\
\text { nature of streets. }\end{array}$ \\
\hline
\end{tabular}

\subsection{Strategic Intervention}

Given the diagnosis and subsequent identification of urban cohesion and sustainability problems in the scoped CBD, we treated the determinant problems first because of their great potential to generate dynamics of change to the other problems. However, the autonomous problems were treated separately because they are not controlled by others.

The intervention strategy treated separately each factor related to the determinant problems (i.e. ACa and FLb). For Aca includes [1] parking on undesignated spaces [2] illegal dumping of refuse on roads and [3] high volume of traffic. While for FLb includes [1] Nature of buildings [2] Storm and water management system and [3] roads.

1. Undesignated Parking: The major causative factor of undesignated parking is the lack of parking lots to cater for the users in the CBD. Thus, this study proposed three intervention strategies tabulated as follows:

Table 3: Intervention strategies in the scoped CBD (ACa)

\section{Interventions Description}

Conversion of parts of

Eid Ground (along IBB road) and Mosque ground (along Murtala Mohammed way) to parking spaces (see figure 15 No. $1 \mathrm{a}$ and $1 \mathrm{~b}$ )

Description
greement by the religious officials, negotia-
tion to compensate the mosque with a multi-
level praying ground could be proposed.
Thus, they got to make maximum use of their
space and also make use of the parking lots
during religious gathering which also attracts
many people (which is a WIN-WIN situa-
tion).
Although a capital intensive project, this
solution will not only reduce problems asso-
ciated with parking deficit but will also elim-
inate illegal dumping in the ditch and induce
various recreational projects such as a park, a
square or an exhibition Centre on the ex-
panse of land near the ditch. There is no
compensation cost involved in this interven-
tion.
Kantin Kwari warehouses are where whole-
sale purchase of goods is done. As a result,
there is influx of trucks in the area that caus-
es significant discomfort to users. Apart
from promoting convenience parking and
eliminating congestion, this intervention will
increase the opportunities to provide utilities,
services and improve the image in the new
area, thus promote the land value of the area.

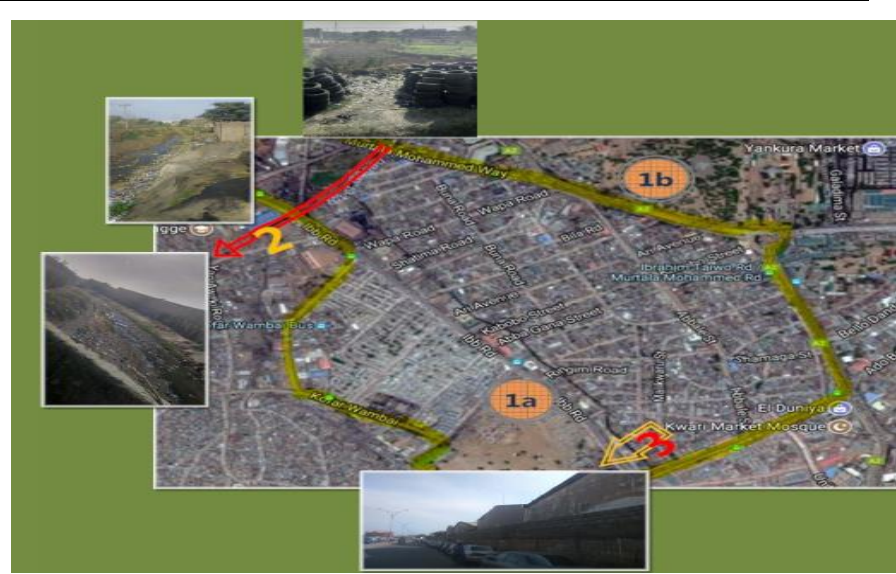

Fig. 19: Intervention strategy No. 1 (source Google map and fieldwork)

The above proposal took into consideration the whole boundary of the study area and particularly major areas where on street parking causes significant problems. Thus, their implementation will reduce on street parking, reduce vehicular-pedestrian conflict, pedestrian accidents (ACb problem solved) and will bring about comfort and maximum usage of spaces (UAc problem solved). In 
addition to these proposals, the city government should create parking policies that will enforce people to use the provided spaces. Alternatively, since controlling parking violators takes expensive man-hours for the local government, the responsibility of the parking securities and maintenance could be giving to private contractors while the city government still earn income from public on-street parking while saving on overhead costs.

\section{Illegal dumping of refuse on roads}

On account of the harmful effects of illegal dumping to the environment, it should be treated as an unlawful and despicable act Thus, this study proposes the following interventions (see table 4):

Table 4: Intervention strategies in the scoped CBD (ACa

\begin{tabular}{|l|l|}
\hline Interventions & \multicolumn{1}{c|}{ Description } \\
\hline Create aware- & $\begin{array}{l}\text { A special taskforce comprising of environmentalist, } \\
\text { nealth, police and local residents should be created to } \\
\text { provide awareness on the adverse effects of illegal } \\
\text { dumping and the advantages of embracing the practice } \\
\text { of 3R i.e. reuse, repair and recycle. In addition, this task } \\
\text { force should solicit for public cooperation and collective } \\
\text { responsibility of reporting illegal dumping. }\end{array}$ \\
\hline $\begin{array}{l}\text { Provision of } \\
\text { waste disposal } \\
\text { facilities }\end{array}$ & $\begin{array}{l}\text { The state authorities should divide the CBD into sectors } \\
\text { then provide waste bins at strategic locations such as } \\
\text { markets, roadsides, and even streets, while reducing } \\
\text { disposal fees at waste management sites. Furthermore, } \\
\text { disposal trucks should be made available to pick up the } \\
\text { waste away from the area. }\end{array}$ \\
\hline $\begin{array}{l}\text { Law enforce- } \\
\text { ment }\end{array}$ & $\begin{array}{l}\text { Law enforcement and prosecution should be prerequi- } \\
\text { site in stopping illegal dumping. Thus, the state authori- } \\
\text { ties should enforce severer illegal dumping laws, while } \\
\text { clearly outlining the consequences and penalties if } \\
\text { caught. The special taskforce mentioned earlier should } \\
\text { be employed to monitor sites where illegal dumping } \\
\text { mostly occurs. }\end{array}$ \\
\hline
\end{tabular}

3. High volume of traffic

The high volume of traffic in the study area is caused by several factors including [1] Inadequate traffic control facilities [2] Illegal erection of temporary shades on roadside, [3] insufficient access routes and [4] poor parking (treated earlier). Thus, this study proposes the following interventions (see table 5).

Table 5: Intervention strategies in the scoped CBD (ACa)

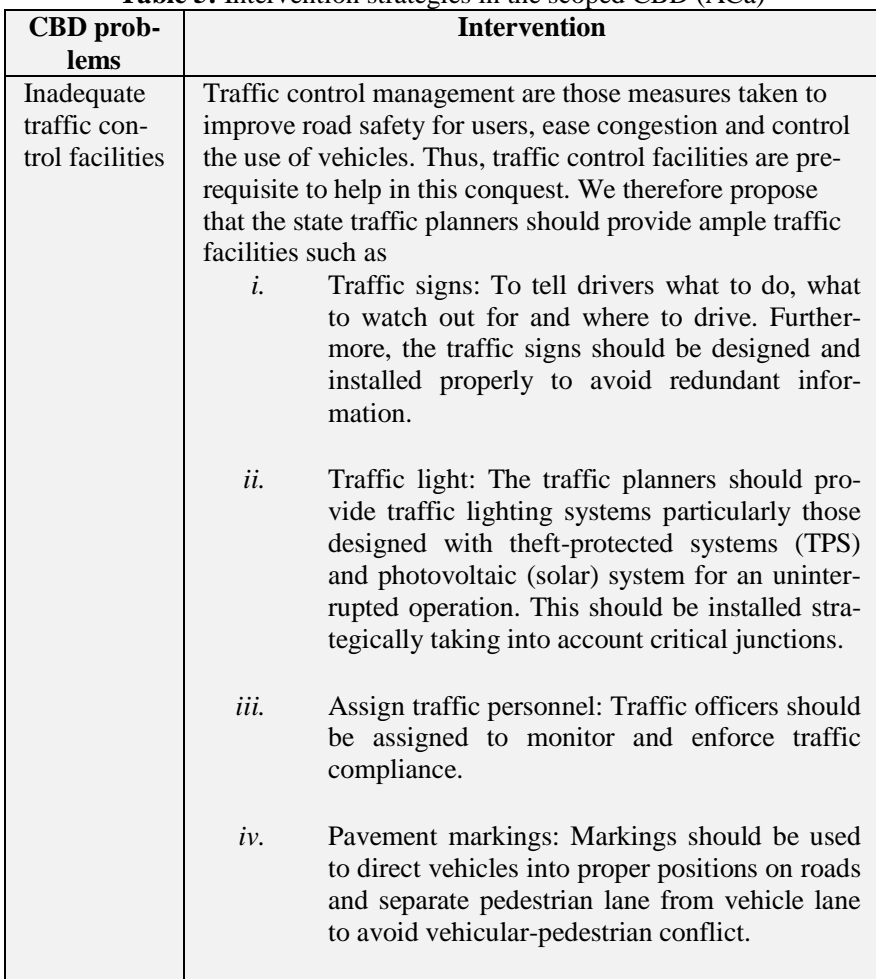

\begin{tabular}{|l|l|}
\hline $\begin{array}{l}\text { Illegal erec- } \\
\text { tion of } \\
\text { temporary } \\
\text { shades on } \\
\text { roadside }\end{array}$ & $\begin{array}{l}\text { It would be unfair to brusquely stop illegal erection of } \\
\text { shades considering the fact that the state revenue service } \\
\text { department collects tax from these people. Therefore, this } \\
\text { study proposes that: } \\
\text { The state authority should identify abandoned } \\
\text { buildings within the CBD and negotiate with } \\
\text { owners on an adaptive reuse strategy to relo- } \\
\text { cate those affected through a win-win nego- } \\
\text { tiation. } \\
\text { Illegal erection of temporary shades by road- } \\
\text { side should then be strictly prohibited by the } \\
\text { state traffic planners and the violators should } \\
\text { be dealt with accordingly. }\end{array}$ \\
\hline $\begin{array}{l}\text { Insufficient } \\
\text { access } \\
\text { routes }\end{array} \mid \begin{array}{l}\text { Restructuring the CBD through widening and } \\
\text { creating routes will be too capital intensive and } \\
\text { will require major relocation exercises. How- } \\
\text { ever, the intervention proposed so far will } \\
\text { nonetheless significantly improve free access. }\end{array}$ \\
ii.
\end{tabular}

The intervention strategies for the second determinant problem (i.e. FLb) are reported herewith (see table 6) and is in consideration of infrastructural problems such as [1] Poor storm and water management system [2] Road problems and [3] poor and abandoned buildings.

Table 6: Intervention strategies in the scoped CBD (FLb)

\begin{tabular}{|c|c|}
\hline Interventions & Description \\
\hline $\begin{array}{l}\text { Improve the } \\
\text { storm water } \\
\text { drainage } \\
\text { system }\end{array}$ & $\begin{array}{l}\text { The channelization of the storm water drainage within } \\
\text { the study area is quite adequate, however, the observable } \\
\text { problems are poor workmanship by the contractors } \\
\text { which results to the cracks in the drainage and poor } \\
\text { design of the drainage due to lack of provision for future } \\
\text { maintenance. Thus the intervention proposes that: } \\
i \text {. The drainage should be unclogged and cov- } \\
\text { ered accordingly with a system of slabbing } \\
\text { that would render maintenance easy and pre- } \\
\text { vent the entrance of any matter that could } \\
\text { clog the drainage. } \\
\text { The state public works department should } \\
\text { pinpoint the critical areas where the drainage } \\
\text { have collapsed such as Abattoir road, IBB } \\
\text { road, Ibrahim Taiwo road etc. and rectified } \\
\text { accordingly. }\end{array}$ \\
\hline $\begin{array}{l}\text { Improve and } \\
\text { construct road }\end{array}$ & $\begin{array}{l}\text { As reported in the analysis section, the roads that need } \\
\text { critical attention are Murtala Mohammed Way (where a } \\
\text { bridge construction was abandoned) and Abattoir, where } \\
\text { the road is virtually destroyed. Therefore, this study } \\
\text { suggests that: } \\
\text { i. The state authorities should consider the } \\
\text { completion of the MM way bridge because of } \\
\text { the major unsustainable problems it creates } \\
\text { such as harboring criminals under the bridge, } \\
\text { undesignated parking, proliferation of waste } \\
\text { etc. } \\
\text { The secondary road networks such as that of } \\
\text { Abattoir road should be tarred (or alternative- } \\
\text { ly paved to reduce cost) and provided with } \\
\text { drainage. }\end{array}$ \\
\hline $\begin{array}{l}\text { Employ adap- } \\
\text { tive reuses } \\
\text { strategy on } \\
\text { abandoned } \\
\text { buildings }\end{array}$ & $\begin{array}{l}\text { It is an aesthetic eyesore to see abandoned buildings with } \\
\text { their image worn out in a CBD. Thus, this study propos- } \\
\text { es that these abandoned be readapted to suit the functions } \\
\text { appropriated for location. }\end{array}$ \\
\hline
\end{tabular}

buildings

It is evident that the intervention strategies proposed for the determinant problems have positive influence on the dependent problems such as ease of access to pedestrians, comfort and maximum usage of spaces, and improved access by people of different generations, social classes, cultures, disabilities etc. (see table 2). While these problems (i.e. the determinant and dependent problems) are dealt with, the proposed intervention strategies for the autonomous and connection problems are reported in table 7 accordingly. 
Table 7: Intervention strategies for both Autonomous and connection problems

\begin{tabular}{|c|c|c|}
\hline & Intervention & Description \\
\hline \multirow{4}{*}{ 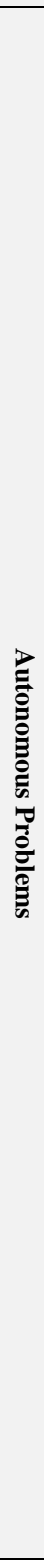 } & $\begin{array}{l}\text { UAb: Provid- } \\
\text { ing a place } \\
\text { for meeting } \\
\text { and socializ- } \\
\text { ing. }\end{array}$ & $\begin{array}{l}\text { Meeting and socializing avenues such as parks, } \\
\text { public green, squares etc. are fundamental re- } \\
\text { quirements to foster social interaction, a sense of } \\
\text { comfort and encourages usage of space among } \\
\text { diverse cross section of the public. Being that } \\
\text { there is no such avenue in the study area, we pro- } \\
\text { pose that: } \\
i \text {. The expanse of land adjacent to the } \\
\text { ditch (former river Gogau) should } \\
\text { be converted to a place for meeting } \\
\text { and socializing (see figure 16-No. } \\
\text { 1). Furthermore, the parking lots } \\
\text { proposed in the area will suit the } \\
\text { project. } \\
\text { The abandoned historic Triumph } \\
\text { Newspaper building of } 1980 \text { should } \\
\text { be readapted for special use such as } \\
\text { museum or the likes (see figure 16- } \\
\text { No. 2) }\end{array}$ \\
\hline & $\begin{array}{l}\text { SIb: Com- } \\
\text { pliment the } \\
\text { activities } \\
\text { appropriated } \\
\text { for the spaces }\end{array}$ & $\begin{array}{l}\text { The CBD was appropriated for mostly commercial } \\
\text { activities, which does not fulfil the requirement } \\
\text { for the delineation of a befitting Central area. } \\
\text { Thus, we propose that other important factors such } \\
\text { as public green, squares, sport complex, institu- } \\
\text { tions etc. should be considered in the study area to } \\
\text { accommodate multiple uses that would promote } \\
\text { social, cultural, political and economic dynamism. }\end{array}$ \\
\hline & $\begin{array}{l}\text { ACc: Ensure } \\
\text { that public } \\
\text { transport } \\
\text { rules and } \\
\text { regulations } \\
\text { are adhered } \\
\text { to }\end{array}$ & 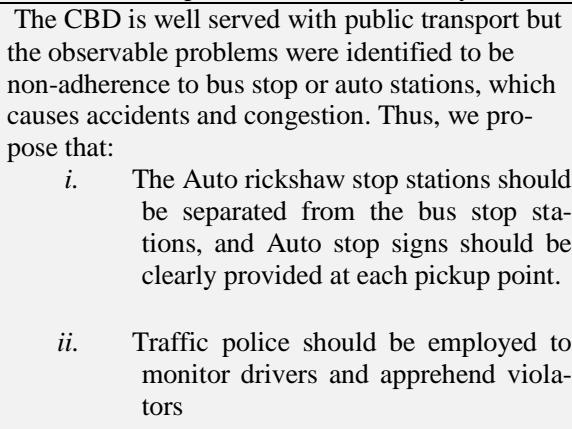 \\
\hline & $\begin{array}{l}\text { SIc: Maintain } \\
\text { and preserve } \\
\text { symbolic or } \\
\text { reference } \\
\text { elements }\end{array}$ & $\begin{array}{l}\text { The symbolic or reference elements present in the } \\
\text { study area such as Kofar Abbale and Kofar Wam- } \\
\text { bai (among the two ancient Gates of Kano) should } \\
\text { be maintained and preserved accordingly. }\end{array}$ \\
\hline 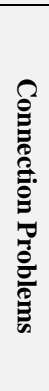 & $\begin{array}{l}\text { Fla: Improve } \\
\text { the layout of } \\
\text { networks }\end{array}$ & $\begin{array}{l}\text { The area of critical concern is the Kofar Wambai } \\
\text { area where there are no good internal connections } \\
\text { that permits internal flow and continuity with its } \\
\text { surroundings. Thus, this study proposes massive } \\
\text { restructuring of the area to create secondary net- } \\
\text { works of roads that could promote ease of access. } \\
\text { This would be a capital-intensive project because } \\
\text { it would require heavy compensation and reloca- } \\
\text { tion exercises. However, it is very important } \\
\text { because in the event of fire outbreak, the area will } \\
\text { be virtually impermeable and the lives and proper- } \\
\text { ties would suffer the consequences of neglect. }\end{array}$ \\
\hline
\end{tabular}

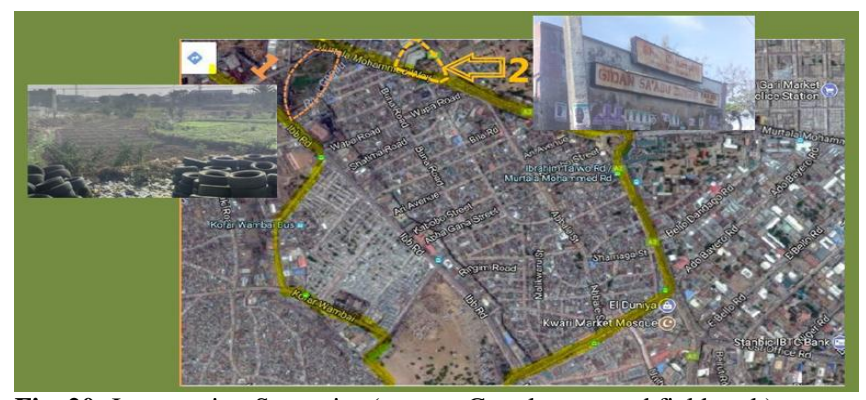

Fig. 20: Intervention Strategies (source: Google map and fieldwork)

\section{Conclusion}

In light of the evaluation of structures and accessibility in this study, we can see that the present Kano CBD have major sustainability and cohesion problems such as poor layout of public space networks that prevents internal continuity with the surroundings, indiscriminate dumping of solid waste that causes all sorts of pollution, undesignated parking that causes accessibility problems and lack of good infrastructural facilities such as roads, drainage systems and buildings which presents an aesthetic eyesore to users. In addition, the lack of multi-functional use of the public spaces for social and cultural activities also limits the potentiality for people to enjoy the CBD accordingly.

In response to the above urban problems, this study proposed a set of urban intervention strategies that would not only improve the visual character of the Kano CBD, but also promote continuity and order in the area, stimulate economic activities, and create diversity of uses that would promote relationships of complementarity with the surrounding networks of Kano metropolis.

However, it is important to note that no amount of interventions and policies would suffice without the political will to follow through and implement the plans. Therefore, we propose that the Government should consider the magnitude of the situations and implement the interventions accordingly by taking into account the needs of present generation without compromising the needs for the future generation.

\section{Acknowledgement}

This is part of an ongoing research to look into the existing urban problems of a particular study area in Kano and proffer sustainable solution to the pressing issues. We cannot forget to mention the Abdulkadir A. Abubakar for his relentless encouragement to pursue research in this particular area/field.

\section{References}

[1] Barau AS (2007), An Account of High Population in Kano State, Northern Nigeria (thesis). Federal College of Education, Kano.

[2] Barau AS, Maconachie, ANM \& Abdulhamid, A (2015), Urban morphology dynamics and environmental change in Kano, Nigeria. Land Use Policy, 42, pp. 307-317.

[3] Bertolini L (1999), Spatial Development Patterns and Public Transport: The Application of an Analytical Model in the Netherlands. Planning Practice and Research 14, 2, pp: 199-210.

[4] Borja, Jordi, Muxi \& Zaida, Public Space: Citizen and Citizenship, Electa Press, (2003), pp: 1-200

[5] Braun B (2005), Environmental issues: writing a more-than-human urban geography. Progress in Human Geography, 29, 635-650.

[6] Carr S, Public Space, Cambridge University Press, (1992), pp: 1230

[7] Commission of European Communities, Third Report on Economic and Social Cohesion: A partnership for cohesion, Publication services for European Union, (2004), pp: 1-30

[8] Dankani IM (2006), Property Developers conceptualization of Planning in Principle and in Practice In Kano Metropolis, MAJASS 4, 2, 101-111.

[9] Era T R , "Improving Pedestrian Accessibility to Public Space through Space Syntax Analysis", 8th International Conference for Space Syntax Symposium, (2012).

[10] Ibrahim A M (2015) Evolutionary Trend, Spatial Distribution Of, and Issues Associated With Markets In Kano Metropolis. International Journal of Physical and Human Geography, 3, 2, 9 24.

[11] Jan V, " Strategic Planning Towards Territorial Cohesion", Conference of European Council of Spatial Planners, Edinburg, (2007).

[12] Liman M A (2015), A Spatial Analysis Of Industrial Growth And Decline In Kano Metropolis, Nigeria (Doctoral thesis). Ahmadu Bello University, Zaria, Nigeria.

[13] Liman M A \& Y M Adamu, Kano in Time and Space: From a City to a Metropolis in Hambolu, M. O. (Ed) Perspectives on Kano- 
British Relations, Gidan Makama Museum Kano Publication (2003).

[14] Lofland L, The Public Realm: Exploring the City's Quintessential Social Territory, Aldine Transaction press, (1998), pp: 1-305

[15] Madanipour A, Design of Urban Space, John Wiley and Sons Ltd, (1996). pp: 158

[16] Makworo M (2012), The Role of Spatial Planning in the Environmental Management of Public Spaces of Residential Neighbourhoods in the City of Nairobi (Doctoral thesis), Jomo Kenyatta University of Agriculture and Technology, Kenya.

[17] Mehta V (2014), Evaluating Public Space, Journal of Urban Design 19, 1, 53-88.

[18] Montgomery J (1998), Making a City: Urbanity, Vitality and Urban Design. Journal of Urban Design 3, 1.

[19] Mougiakou E \& Photis, Y N (2014), Urban Green Space Network Evaluation And Planning: Optimizing Accessibility Based On Connectivity And Raster Gis Analysis. European Journal of Geography 5, 4, 19-46.

[20] Mustapha ID (2013), Constraints to Sustainable Physical Planning in Metropolitan Kano, International Journal of Management and Social Sciences Research 2,3,34-42.

[21] National Population Commission, Population Estimate for the Kano Metropolitan Area,Indabawa press, (2014), pp:12-14.

[22] Nicholls S (2001), Measuring the accessibility and equity of public parks: a case study using GIS. Managing Leisure, 6, 201-219.

[23] Pasaogullari N. \& Doratly, N (2004), Measuring Accessibility and Utilization of Public Spaces in Famagusta. Journal of Cities 2, 13, $225-232$.

[24] Pinto A \& Remasar, A ,"Planning public spaces networks towards urban cohesion", 46th ISOCARP Congress, (2010), pp: 16-26

[25] Pinto A.\& Remasar, A (2015), Urban Cohesion: A Public Space Network Assessment, Centro de Sistemas Urbanos e Regionais, 39, $2,7-25$.

[26] Pollock S.(2014), Production, Use, and Barriers to Access in Public Space: A comparative Case Study in Metro Atlanta, GA, USA (Degree thesis), Cardiff University.

[27] Sanusi B M (1998), Planning for the provision of parking Facilities in the C.B.D of Kano (Masters thesis). Ahmadu Bello University, Zaria. Nigeria.

[28] Spaargaren G, Mol A P G, \& Buttel FH, Environment and global modernity, Sage publication, (2000), pp: 449

[29] Talen E City rules, How regulations affect urban form, Island Press, (2012), pp: 236 